\title{
Pemberdayaan Ekonomi Masyarakat Melalui Inovasi Bisnis Dalam Memanfaatkan Bahan Lokal Di Desa Cimanggu Satu
}

\section{Community Economic Empowerment Through Business Innovation In Utilizing Local Materials In The Cimanggu One Village}

\author{
Lili Andriyani ${ }^{1}$, Andri Brawijaya ${ }^{2}$ \\ 1Program Studi Ekonomi Syariah Fakutas Ekonomi Ekonomi Islam Universitas Djuanda Bogor, Jl Tol Ciawi \\ No.1 Kotak Pos 35 Bogor 16720, e-mail: lili.andriyani@unida.ac.id \\ 2Program Studi Perbankan Syariah Fakutas Ekonomi Ekonomi Islam Universitas Djuanda Bogor, Jl Tol \\ Ciawi No.1 Kotak Pos 35 Bogor 16720, e-mail: andribrawijaya@unida.ac.id
}

(Diterima: 25-06-2020; Ditelaah: 15-12-2020; Disetujui: 10-06-2021)

\begin{abstract}
Abstrak
Inovasi adalah suatu pembaharuan terhadap berbagai sumber daya sehingga sumber daya tersebut mempunyai manfaat yang lebih bagi manusia. Proses inovasi sangat dipengaruhi oleh kemajuan teknologi dan ilmu pengetahuan karena kedua hal tersebut dapat memudahkan dalam memproduksi sesuatu yang baru dan berbeda. Pada dasarnya manfaat inovasi adalah untuk menyempurnakan atau meningkatkan fungsi dari pemanfaatan suatu produk atau sumber daya sehingga manusia mendapatkan manfaat yang lebih. Inovasi terjadi di berbagai bidang kehidupan, mulai dari dunia bisnis, pendidikan, komunikasi, dan lain sebagainya. Hasil penelitian menunjukkan bahwa pemanfaatan hasil sumber daya alam pada masyarakat berpotensi untuk meningkatkan nilai ekonomi dari hasil pertanian dan perkebunan di daerah tersebut.
\end{abstract}

Kata kunci: Bisnis, Ekonomi, Inovasi

\begin{abstract}
Innovation is a renewal of various resources so that these resources have more benefits for humans. The process of innovation is greatly influenced by technological and scientific advances because both can make it easier to produce something new and different. Basically, the benefits of innovation are to perfect or improve the function of utilizing a product or resource so that humans get more benefits. Innovations occur in various fields of life, ranging from the world of business, education, communication, and so forth. The results showed that the utilization of natural resource products in the community has the potential to increase the economic value of agricultural and plantation products in the area.
\end{abstract}

Keywords: Business, Economic, Inovation

\section{PENDAHULUAN}

Inovasi dibutuhkan dalam suatu bisnis. Inovasi umumnya dianggap sebagai aspek penting dari sebagian proses bisnis karena dapat memberikan keunggulan kompetitif (Ellitan, 2009:19). Inovasi produk merupakan hasil dari pengembangan produk baru oleh suatu perusahaan atau industri, baik yang sudah ada maupun belum. Dari produk lama yang telah mencapai titik jenuh di pasaran, diperlukan sebuah inovasi untuk mengganti produk lama tersebut. Penggantian ini dapat berupa produk pengganti yang secara total baru atau dengan perkembangan produk lama yang lebih modern dan up to date, sehingga dapat terus meningkatkan keinginan konsumen dalam keputusan pembelian produk tersebut (Indriany, 2013:67-68).

Inovasi produk merupakan sebagai proses pengenalan produk atau sistem baru yang membawa kesuksesan ekonomi bagi perusahaan dan kesuksesan sosial bagi 
konsumen serta komunitas atau lingkungan yang lebih luas (Kotler dan Keller, 2009:154). Inovasi dalam konteks birokrasi diamanatkan dalam Undang-undang menjadi salah satu pendorong untuk percepatan pembangunan, hal ini sudah terbukti dengan model yang diterapkan di negara maju. Dewasa ini, peningkatan produktivitas tidak hanya bergantung pada pada ilmu pengetahuan dan teknologi melainkan pada ketersediaan sumber daya alam yang dimiliki. Pengembangan kewirausahaan menduduki peran yang sangat strategis makin signifikan. Kita harus mendorong dan mengembangkan kemampuan wirausaha, memanfaatkan peluang bisnis dalam dinamika persaingan global (Prasetyo, 2018)

Inovasi adalah kesuksesan ekonomi dan sosial berkat diperkenalkannya cara baru atau kombinasi baru dari cara-cara lama dalam mentransformasi input menjadi output yang menciptakan perubahan besar dalam hubungan antara nilai guna dan harga yang ditawarkan kepada konsumen dan/atau pengguna, komunitas, sosietas dan lingkungan. Hampir sama dengan inovasi organisasi menurut Sutarno (2012:134-135) yang didefinisikan sebagai cara-cara baru dalam pengaturan kerja, dan dilakukan dalam sebuah organisasi untuk mendorong dan mempromosikan keunggulan kompetitif. Inti dari inovasi organisasi adalah kebutuhan untuk memperbaiki atau mengubah suatu produk, proses atau jasa. Inovasi organisasi mendorong individu untuk berpikir secara mandiri dan kreatif dalam menerapkan pengetahuan pribadi untuk tantangan organisasi. Semua organisasi bisa berinovasi termasuk untuk organisasi perusahaan, rumah sakit, universitas, dan organisasi pemerintahan. Pentingnya nilai, pengetahuan dan pembelajaran dalam inovasi organisasi sangat penting.

Salah satu upaya pemerintah dalam mendukung peningkatan Usaha Kecil Mikro Menengah (UKM) adalah diterbitkannya Undang-Undang No 19 Tahun 2003 tentang Badan Usaha Milik Pemerintah (BUMN) sebagai wujud kepedulian terhadap pertumbuhan ekonomi masyarakat (Pandji \& Supriyono, 2008). Adapun tujuan dari pelaksanaan penelitian ini sebagai berikut:

1. Menumbuhkan semangat masyarakat untuk berwirausaha dengan melakukan sosialisai inovasi produk potensi desa sehingga dapat memberikan ide kepada masyarakat untuk berfikir lebih kreatif terhadap potensi alam yang sudah melimpah.

2. Menumbuhkan semangat masyarakat untuk memanfaatkan waktu luang dengan menghasilkan produk baru dari potensi alam yang sudah ada.

3. Memanfaatkan hasil pertanian dan perkebunan bagi masyarakat.

4. Meningkatkan kesadaran masyarakan akan pentingnya inovasi produk.

Program yang dilakukan penulis berupa program pendampingan ekonomi masyarakat dengan cara membentuk kelompok usaha yang akan mengembangkan potensi sumber daya alam yang ada di sekitar wilayah desa Cimanggu Satu. Sumber Daya Alam yang dihasilkan Desa Cimanggu Satu sangat melimpah, akan tetapi sumber daya alam yang dimiliki Desa Cimanggu Satu belum sepenuhnya dimanfaatkan oleh masyarakat, sehingga perlu adanya bimbingan atau pendampingan kepada masyarakat 
untuk memanfaatkan potensi yang ada. Salah satunya dengan memanfaatkan produk olahan pepaya yang dibuat menjadi sebuah makanan dengan harga nilai jual tinggi.

Pemilihan program pemanfaatan olahan pepaya ini dilakukan karna melihat potensi buah pepaya yang melimpah akan tetapi harga nilai jual buah pepaya terbilang sangat rendah. Pepaya banyak dibudiyakan oleh masyarakat baik sebagai hobi ataupun usaha komersil. Hal ini karena pepaya memiliki kelebihan di antaranya dapat dibudidayakan di pekarangan atau kebun, cepat berbuah dan mampu berbuah lebat, rasanya manis, tumbuh tanpa perawatan yang rumit dan kandungan gizi yang cukup banyak. Buah pepaya tergolong buah yang populer dan digemari oleh hampir seluruh penduduk penghuni bumi. Daging buahnya lunak dengan warna merah dan kuning, rasanya manis dan menyegarkan karena mengandung banyak air. Nilai gizi buah pepaya cukup tinggi karena mengandung banyak provitamin A, vitamin C, dan kalsium (Kalie, 2008).

\section{METODE PELAKSANAAN}

Bentuk pelaksanaan penelitian pembuatan produk olahan pepaya ini dengan menggunakan pelatihan demo masak dan cara pengemasan kepada masyarakat sekitar. Pelaksanaan kegiatan pengabdian Kepada Masyarakat dilaksanakan di Desa Cimanggu Satu Kecamatan Cibungbulang Kabupaten Bogor dengan melakukan pelatihan pembuatan inovasi produk

\section{HASIL \& PEMBAHASAN}

Bentuk pelaksanaan penelitian pembuatan produk olahan pepaya ini dengan menggunakan pelatihan demo masak dan cara pengemasan kepada masyarakat sekitar, bahan-bahan yang diperlukan dan cara yang digunakan adalah sebagai berikut:

Bahan-bahan:

1. $1,5 \mathrm{~kg}$ pepaya

2. $1 \mathrm{~kg}$ minyak goreng

3. 20 siung bawang merah

4. 4 siung bawang putih

5. $3 \mathrm{~cm}$ jahe

6. $3 \mathrm{~cm}$ lengkuas

7. 3 sereh

8. 1 sendok garam

9. 1 penyedap rasa

10. 4 sendok tepung beras

11. 2 sendok tepung terigu

12. 2 sendok tepung sagu

13. 2 sendok ketumbar bubuk 
Cara pembuatan:

a) Kupas pepaya mentah, parut pepaya menggunakan parutan sayur, bersihkan pepaya menggunakan air, dan tuangka 1 sendok garam ke dalam parutan pepaya, aduk rata sambil tekan parutan pepaya tersebut, bilas dengan air bersih sebanyak 3 kali dan tiriskan sampai kering.

b) Parut semua bahan bumbu menggunakan parutan halus atau parutan kelapa di antaranya:

1. 10 Siung Bawang Merah

2. 4 Siung Bawang Putih

3. 2 Batang Sereh

4. $3 \mathrm{~cm}$ Lengkuas

5. $3 \mathrm{~cm}$ Jahe

c) Masukan bumbu halus tersebut ke dalam parutan pepaya yang sudah bersih, kemudian masukan 2 sendok garam, 1 sachet kaldu ayam, 1 sendok penyedap rasa, aduk hingga merata.

d) Siapkan tepung di wadah, di antaranya:

1. 2 sendok makan tepung terigu

2. 2 sendok makan tepung sagu

3. 4 sendok makan tepung beras, aduk hingga merata

e) Ambil parutan pepaya yang sudah dibumbui ke dalam saringan (ayakan) kemudian tabur dengan campuran tepung sembil di goyangkan secara perlahan sampai pepaya merata diselimuti tepung

f) Panaskan minyak kemudian goring pepaya tersebut secara perlahan, sambil di aduk pepaya ke dalam penggorengan sampai berwarna kecoklatan kemudian tiriskan

g) Setelah ditiriskan, kemas pepaya ke dalam kemasan yang menarik.

Produk yang dihasilkan dari kegiatan Program ini adalah pemanfaatan buah pepaya yang diolah dan diberi nama "Pepaya Kriyuk Priyuk". Pembuatan produk tersebut bertujuan untuk meningkatkan nilai jual buah pepaya dan mempunyai nilai ekonomi yang tinggi untuk masyarakat Desa Cimanggu Satu. Berikut capaian keperhasilan yang dalam program pembuatan olahan buah pepaya.

Produk yang dihasilkan adalah produk olahan singkong yang diberi nama "Pepaya Kriyuk Priyuk", dengan dibuatnya produk ini diharapkan masyarakat dapat mengembangkan sumber daya alam dengan lebih variatif sehingga menaikan harga jual, masyarakat lebih memahami cara mengelola buah pepaya agar menjadi sebuah produk yang memiliki nilai jual tinggi dan masyarakat memiliki motivasi untuk mengembangkan produk tersebut. 


\section{KESIMPULAN}

Pelaksanaan kegiatan pengabdian Kepada Masyarakat dilaksanakan di Desa Cimanggu Satu Kecamatan Cibungbulang Kabupaten Bogor dengan melakukan pelatihan pembuatan inovasi produk. Penulis dalam pelaksanaan program individu membuat sebuah produk yang memanfaatkan buah pepaya, hal ini dilakukan melihat potensi buah pepaya yang pemanfaatannya tidak optimal, selain itu harga jual pepaya pun terbilang murah.

Pengembangan produk pepaya menjadi produk yang unik dan baru merupakan tujuan dari program individu ini, produk Pepaya "Kriyuk Priyuk" menjadi salah satu alternatif pemanfaatan potensi alam yang dimiliki. Dalam pemanfaatan produk pepaya ini penulis dilakukan mengolah pepaya dengan baik dan menarik. Pembuatan logo produk menjadi salah satu cara untuk menarik perhatian konsumen juga meningkatkan nilai jual, penjualan produk ini bisa dilakukan dengan menjualnya secara pribadi, dimasukan ke dalam warung-warung, sebagai oleh-oleh khas desa dijual secara online, penjualan via media sosial dan lain-lain. Kegiatan program pembuatan produk olahan pepaya ini dapat menjadi solusi peningkatan perekonomian masyarakat desa Cimanggu satu melalui pemanfaatan sumber daya alam.

Adapun saran penulis yaitu agar masyarakat dapat lebih memanfaatkan hasil perkebunan dan mengolah hasil alam yang kreatif dan semakin banyak masyarakat yang ingin berwirausaha dapat melakukan kerjasama antara mahasiswa KKN dengan warga setempat dalam meningkatkan pemasaran.

\section{DAFTAR PUSTAKA}

Ellitan, Lena dkk. 2009. Manajemen Sumber Daya Manusia Dalam Bisnis Modern. Alfabeta, Bandung.

Fontana, Avanti 2009. Innovate we can! Manajemen Inovasi dan Penciptaan Nilai Jakarta: Gramedia Widiasarana Indonesia.

Indriani, Dian. 2013. Peranan Job Description dalam Memperlancar Aktivitas Kerja Karyawan pada PT Jasaraharja Putera Palembang. Laporan Akhir Jurusan Administrasi Bisnis. Palembang: Politeknik Negeri Sriwijaya.

Kalie, M B. 2008. Bertanam Pepaya (Edisi Revisi). Penebar Swadaya : Jakarta

Kotler, Philip. 2009. Manajemen pemasaran, Edisi Millenium, Jilid 2, PT Prenhallindo, Jakarta

Lestari Citra, Lubis Nawazirul, Widayanto. 2015, Pengaruh Jaringan Usaha, Inovasi Produk dan Persaingan Usaha Terhadap Perkembangan Usaha Mikro, Kecil dan Menengah, Jurusan Administrasi Bisnis, Fakultas Ilmu Sosial dan Ilmu Politik, Universitas Diponegoro, Semarang. 
Pemberdayaan Ekonomi Masyarakat melalui Inovasi Bisnis dalam Memanfaatkan Bahan Lokal di Desa Cimanggu Satu

Pandji, Dwi dan Winda Wardhani. 2013. Sudahkah Kita Ramah Anak Special Needs?. Jakarta: PT Elex Media Komputindo Kelompok Gramedia.

Prasetyo, Bambang. 2008. Lina Miftahul Jannah, Metode Penelitian Kuantitatif: Teori dan Aplikasi, Jakarta: PT Raja Grafindo Persada, 2008.

Supriyono, Widodo \& Abu Ahmadi.2008 Psikologi belajar. Jakarta: PT Rineka Cipta. 